\section{Ni phases formed in cement and cement systems under highly alkaline conditions: an XAFS study}

\author{
André M. Scheidegger, ${ }^{a+}$ Erich Wieland, ${ }^{a}$ \\ Andreas C. Scheinost, ${ }^{b}$ Rainer Dähn, ${ }^{a}$ Jan Tits ${ }^{a}$ \\ and Peter Spieler ${ }^{\mathrm{a}}$
}

\author{
${ }^{a}$ Waste Management Laboratory, Paul Scherrer Institute, 5232 \\ Villigen, Switzerland. \\ 'Institute for Terrestrial Ecology, Swiss Federal Institute of \\ Technology (ETHZ), 8952 Schlieren, Switzerland. \\ Andre.Scheidegger@psi.ch
}

X-ray absorption fine structure (XAFS) spectroscopy was applied to assess the solubility-limiting phase of $\mathrm{Ni}$ in cement and cement minerals. The study reveals the formation $\mathrm{Ni}$ and $\mathrm{Al}$ containing hydrotalcite-like layered double hydroxides (Ni-Al LDHs) when cement material (a complex mixture of $\mathrm{CaO}, \mathrm{SiO}_{2}, \mathrm{Al}_{2} \mathrm{O}_{3}, \mathrm{Fe}_{2} \mathrm{O}_{3}$ and $\mathrm{SO}_{3}$ ) was treated with $\mathrm{Ni}$ in artificial cement pore water under highly alkaline conditions $(\mathrm{pH}=13.3)$. This finding indicates that $\mathrm{Ni}-\mathrm{Al}$ LDHs and not Ni-hydroxides determine the solubility of $\mathrm{Ni}$ in cement materials.

Keywords: cement, $\mathrm{Ni}$, layered double hydroxides, XAFS

\section{Introduction}

Cementitious materials are commonly used worldwide in immobilization strategies for the disposal of hazardous and radioactive waste (Glasser, 1993; Gougar et al., 1996). For the uptake of $\mathrm{Ni}$ by blended cement several uptake modes have been discussed (Atkins et al., 1994): the formation of a 4:1 Ca:Ni phase (which is thought to replace $\mathrm{Ni}(\mathrm{OH})_{2}$ as the solubility-limiting phase in cement systems), the presence of a poorly crystallized $\mathrm{Ni}(\mathrm{OH})_{2}$ gel and the formation of a $\mathrm{Ni}$ and $\mathrm{Al}$ containing hydrotalcite-like layered double hydroxide (Ni-Al LDH). Recent XAFS studies have shown that the formation of $\mathrm{Ni}-\mathrm{Al} \mathrm{LDHs}$ can immobilize $\mathrm{Ni}$ and other heavy metal ions under neutral and slightly alkaline conditions in laboratory systems containing $\mathrm{Al}(\mathrm{hydr}$ )oxides or clay minerals (Scheidegger et al., 1997; Towle et al et al., 1997, Scheidegger et al., 1998; Scheinost et al., 1999a; Thompson et al.; 1999; Scheinost et al., 2000). In the present study we used XAFS to investigate the nature of the Ni phases formed with cement and cement constituents under the conditions relevant to cement systems $(\mathrm{pH}=13.3)$.

\section{Materials and Methods}

\subsection{Solids}

The solids used in this study were quartz, calcium silicate hydrate (csh), portlandite $\left(\mathrm{Ca}(\mathrm{OH})_{2}\right)$, gibbsite $\left(\mathrm{Al}(\mathrm{OH})_{3}\right)$ and the size fraction $\leq 70 \mu \mathrm{m}$ of a commercial Portland cement (trade name CPA 55 HTS, Lafarge, France). The composition of the cement material was 66.4 wt. $\% \mathrm{CaO}, 23.8$ wt.\% $\mathrm{SiO}_{2} 2.7$ wt. $\% \mathrm{Al}_{2} \mathrm{O}_{3}, 2.8$ wt. $\% \mathrm{Fe}_{2} \mathrm{O}_{3}$ and 1.8 wt. $\% \mathrm{SO}_{3}$ as the main chemical compounds. Ni sorption experiments were carried out by adding aliquots of a $0.1 \mathrm{M} \mathrm{Ni}$ solution $\left(\mathrm{Ni}\left(\mathrm{NO}_{3}\right)_{2} \cdot 6 \mathrm{H}_{2} \mathrm{O}\right) \mathrm{Ni}$ to an artificial cement pore water $(\mathrm{ACW}$; solid/liquid: $2.510^{-2} \mathrm{~kg} \mathrm{~L}^{-1}$ ). The samples were shaken end-over-end in a glove box under a $\mathrm{N}_{2}$ atmosphere $\left(\mathrm{CO}_{2}<5 \mathrm{ppm}, \mathrm{O}_{2}<5 \mathrm{ppm}\right)$ for 150 days and then centrifuged. The composition of ACW was equivalent to the chemical composition of a solution in equilibrium with freshly prepared pulverized hardened cement paste. Under these conditions, the pore water is a $(\mathrm{Na}, \mathrm{K}) \mathrm{OH}$ rich fluid saturated with respect to portlandite $(\mathrm{pH}=13.3)$. Details on solid characterization and preparation of ACW are described elsewhere (Wieland et al., 1998, Tits et al., 2000).

XAFS spectra were collected at beamline X-11A (NSLS, Brookhaven National Laboratory, Upton, NY) using a $\mathrm{Si}(111)$ crystal monochromator. Fluorescence spectra were measured at room temperature using a solid-state detector (13-element detector, Canberra). The measurements were recorded in $\mathrm{N}_{2}$ atmosphere to prevent $\mathrm{CO}_{2}$ contamination. Further details on the experimental setup and data collection are described elsewhere (Scheidegger et al., 1997; Scheidegger et al., 1998). XAFS data reduction was performed using WinXAS 971.3 software package following standard procedures (Ressler, 1998). Multishell fits were performed in real space across the range of the first two shells $(\Delta \mathrm{k}=3.2$ $12.0 \AA^{-1}$ (cement sample: $3.2-10.0 \AA^{-1}$ ); $\Delta \mathrm{R}=0.5$ to $4 \AA$ ). Theoretical scattering paths for the fit were calculated with FEFF 8.0 (Rehr et al., 1991), using the structures of $\beta-\mathrm{Ni}(\mathrm{OH})_{2}$ and hydrotalcite (Bellotto et al., 1996). The amplitude reduction factor, $\mathrm{S}_{0}{ }^{2}$, was fixed at 0.85 (O'Day et al., 1994). The $\mathrm{R}_{\mathrm{Ni}-\mathrm{O}}$ and $\mathrm{R}_{\mathrm{Ni}-\mathrm{Ni}}$ values are estimated to be accurate to $\pm 0.02 \AA$, and $\Delta \mathrm{E}_{0}$ values and the $\mathrm{CN}_{\mathrm{Ni}-\mathrm{O}}$ and $\mathrm{CN}_{\mathrm{Ni}-\mathrm{Ni}}$ values are estimated to be accurate to $\pm 20 \%$ (Scheidegger et al., 1998). Reference compounds used were $\beta$ $\mathrm{Ni}(\mathrm{OH})_{2}, \alpha-\mathrm{Ni}(\mathrm{OH})_{2}, \quad \mathrm{Ni}$-phyllosilicate, and $\mathrm{Ni}-\mathrm{Al} \mathrm{LDH}$ phases (takovite $\left(\mathrm{Ni}_{6} \mathrm{Al}_{2}(\mathrm{OH})_{16} \mathrm{CO}_{3} \cdot \mathrm{H}_{2} \mathrm{O}\right)$, a natural mineral and a synthetic $\mathrm{Ni}-\mathrm{Al} \mathrm{LDH}$ phase with an overall $\mathrm{Ni}$ :Al ratio of 1.3 ). Since for crystal chemical reasons the $\mathrm{Ni}$ :Al ratio in $\mathrm{Ni}-\mathrm{Al} \mathrm{LDHs}$ can not be lower than 2:1 (Bish and Brindley, 1977), it must be assumed that the synthetic phase contained impurities such as amorphous Al(hydr)oxides. Synthesis and characterization of the reference compounds are described elsewhere (Scheinost et al., 1999a).

\section{Results and Discussions}

Fig. 1 shows the normalized, background subtracted and $\mathrm{k}^{3}$-weighted $\mathrm{Ni}-\mathrm{XAFS}$ spectra. The figure reveals that the $\mathrm{k}^{3} \chi(\mathrm{k})$ spectra of the $\mathrm{Ni}$ treated cement and gibbsite samples are similar to the spectra of takovite and the synthetic mixed $\mathrm{Ni}-\mathrm{Al} \mathrm{LDH}$ phase (syn. Ni-Al LDH), suggesting a similar structural environment. It has been demonstrated that a distinctive beat pattern between 8.0 and $8.5 \AA^{-1}$ in the $\mathrm{k}^{3} \chi(\mathrm{k})$ spectrum can be used as a fingerprint to unequivocally identify the presence of Ni-Al LDHs (Scheinost et al., 2000). Indeed, Fig. 1 reveals the presence of this distinctive beat pattern at about $8 \AA^{-1}$ in the Ni cement sample (see dashed lines in Fig. 1). Moreover, the beat pattern at about $8 \AA^{-1}$ is similar to the beat pattern in the spectra of Ni-gibbsite, takovite and the synthetic Ni-Al LDH phase. While for Ni-Al LDHs the oscillation at about $8 \AA^{-1}$ is truncated, other reference compounds and $\mathrm{Ni}$ treated cement constituents ( $\alpha$ and $\beta-\mathrm{Ni}(\mathrm{OH})_{2}$, Ni-phyllosilicate, Ni/csh, and $\mathrm{Ni}$ /quartz) show an elongated upward oscillation ending in a sharp tip at $\approx 8.5 \AA^{-1}$. Full multiple scattering simulations and experimental spectra of model compounds indicate that the beat pattern is due to the combination of focused multiple scattering of $\mathrm{Ni}$ and $\mathrm{Al}$ (Scheinost et al., 2000). Thus, the presence of this feature in the $\mathrm{k}^{3} \chi(\mathrm{k})$ spectrum clearly demonstrates that a Ni-Al LDH phase has been formed in Ni doped cement sample. 


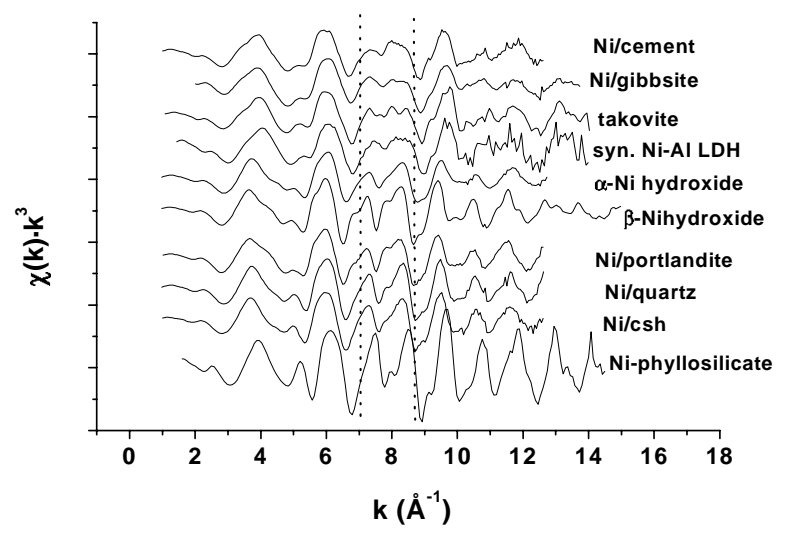

Figure 1

$\mathrm{k}^{3}$-weighted, normalized, background-subtracted XAFS spectra of Ni treated cement, $\mathrm{Ni}$ treated gibbsite, takovite, a synthetic Ni-Al LDH, $\alpha-\mathrm{Ni}(\mathrm{OH})_{2}, \beta$ $\mathrm{Ni}(\mathrm{OH})_{2}$, Ni treated portlandite, $\mathrm{Ni}$ treated quartz, $\mathrm{Ni}$ treated $\mathrm{CSH}$ and a synthetic Ni-phyllosilicate. The vertical dashed lines localize the region of the distinctive beat pattern at $\sim 8 \AA^{-1}$ characteristic for $\mathrm{Ni}-\mathrm{Al} \mathrm{LDH}$ phases.

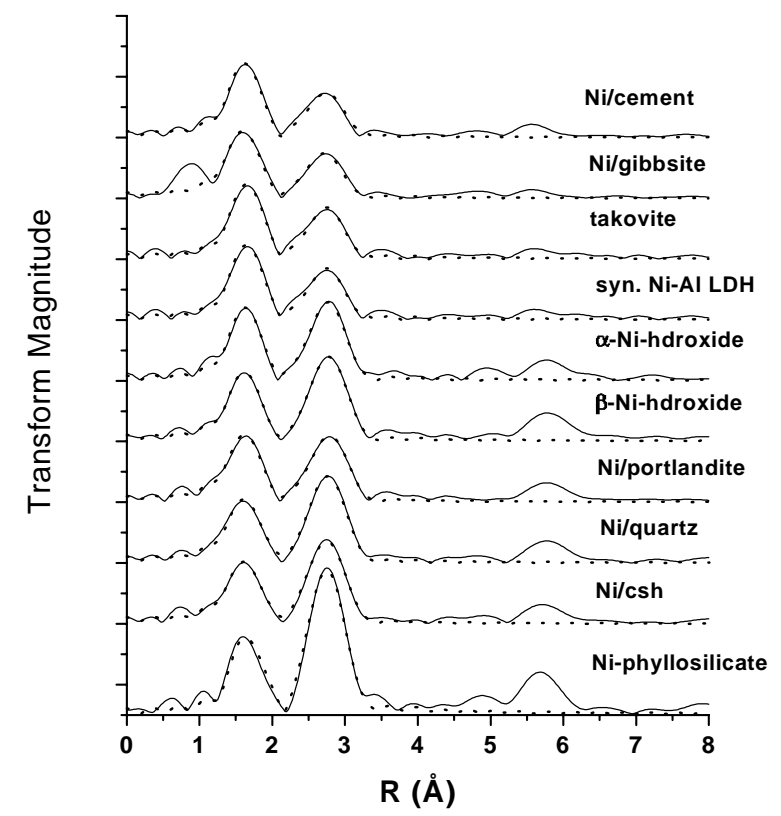

Figure 2

Fourier transforms (uncorrected for phase shift) of the $\mathrm{k}^{3} \chi(\mathrm{k})$ spectra shown in Fig.1. The solid line represents the experimental data and the dashed line the fit.

The structural parameters derived from multishell XAFS analysis are summarized in Tab. 1. The table reveals that in the first coordination shell $\mathrm{Ni}$ is surrounded by $\sim 6$ oxygen atoms at $2.04-2.06 \AA$. This behavior indicates that $\mathrm{Ni}$ (II) is coordinated in an octahedral environment. For all samples fitting of the second radial structure function (RSF) peak was performed by using $\mathrm{Ni}$ alone since discrimination of $\mathrm{Ni}-\mathrm{Ni}$ and $\mathrm{Ni}-\mathrm{Si} / \mathrm{Al}$ backscattering in $\mathrm{Ni}-\mathrm{Al} \mathrm{LDH}$ and $\mathrm{Ni}$ phyllosilicate phases is problematic (Manceau \& Calas, 1985; Manceau \& Calas, 1986; Towle et al., 1997; Thompson et al., 1999; Scheinost et al., 2000). Tab. 1 shows that, as expected, the $\mathrm{Ni}$ $\mathrm{Ni}$ coordination number $\left(\mathrm{CN}_{(\mathrm{Ni}-\mathrm{Ni})}\right)$ in $\beta-\mathrm{Ni}(\mathrm{OH})_{2}$ is close to 6 . In Niphyllosilicates, however, the $\mathrm{CN}_{\mathrm{Ni}-\mathrm{Ni}}$ is greater than 6 due to the constructive interference of $\mathrm{Si}$ in the tetrahedral sheets at a distance between 3.2-3.3 $\AA$ resulting in an enhancement of the overall amplitude (Charlet \& Manceau, 1994; Manceau et al., 1999). In spite of the experimental error, it is possible (but not conclusive) that in the $\mathrm{Ni} / \mathrm{csh}$ and $\mathrm{Ni} /$ quartz samples the $\mathrm{CN}_{(\mathrm{Ni}-\mathrm{Ni})}$ 's $(6.4$ and 6.3) are also slightly enhanced due to at least partly the neoformation of a Ni-phyllosilicate phase in the reaction system. This explanation would agree with recent XAFS findings that the uptake of Co and $\mathrm{Zn}$ onto quartz and clay surfaces at neutral and slightly alkaline $\mathrm{pH}$ conditions can result in the neoformation of $\mathrm{Co}-$ and $\mathrm{Zn}$ phyllosilicate phases (Manceau et al., 1999; Schlegel et al., 2001). In the synthesized Ni-Al LDH sample, however, the number of second shell neighbor atoms obtained is clearly reduced $\left(\mathrm{CN}_{(\mathrm{Ni}-\mathrm{Ni})}=\right.$ 2.8). In Ni-Al LDHs $\mathrm{Al}$ is partially substituted by $\mathrm{Ni}$ resulting in a significant destructive interference between the Ni and the Al XAFS contribution and in an amplitude cancellation between the $\mathrm{Ni}$ and $\mathrm{Al}$ shells. The same characteristic is observed for $\mathrm{CN}_{\mathrm{Ni}-\mathrm{Ni}}$ in takovite $\left(\mathrm{CN}_{(\mathrm{Ni}-\mathrm{Ni})}=3.1\right)$ as well as for $\mathrm{CN}_{\mathrm{Ni}-\mathrm{Ni}}$ 's in the Ni treated cement and gibbsite samples $\left(\mathrm{CN}_{(\mathrm{Ni}-\mathrm{Ni})}=2 \cdot 7-3 \cdot 2\right)$. For this reason, the $\mathrm{CN}_{\mathrm{Ni}-\mathrm{Ni}}$ 's determined by data analysis further support our finding that a $\mathrm{Ni}-\mathrm{Al}$ LDH phase is formed in the cement sample. In Fig. 2 the Fourier transforms of the $\mathrm{k}^{3} \chi(\mathrm{k})$ spectra are shown in comparison with the fit. The figure illustrates the findings discussed above. In Ni-Al LDH phases the amplitude of the second shell peak is clearly reduced (due to the destructive interference between the $\mathrm{Ni}$ and the $\mathrm{Al}$ XAFS contribution) compared to $\alpha$ and $\beta-\mathrm{Ni}(\mathrm{OH})_{2}$.

Table 1

Structural Information Derived from XAFS Analysis

\begin{tabular}{|c|c|c|c|c|c|c|c|c|}
\hline & \multicolumn{3}{|c|}{$\mathrm{Ni}-\mathrm{O}$} & \multicolumn{3}{|c|}{$\mathrm{Ni}-\mathrm{Ni}$} & \multirow[b]{2}{*}{$\begin{array}{l}\Delta \mathrm{E}_{0} \\
{[\AA]}\end{array}$} & \multirow[b]{2}{*}{$\chi_{\text {res } \%}^{2}$} \\
\hline & $\mathrm{CN}$ & $\begin{array}{c}\mathrm{R} \\
{[\AA]}\end{array}$ & $\begin{array}{c}\Delta \sigma^{2} \\
{\left[\AA^{2}\right]} \\
10^{-3}\end{array}$ & $\mathrm{CN}$ & $\begin{array}{c}\mathrm{R}_{\mathrm{Ni}-\mathrm{Ni}} \\
{[\AA]}\end{array}$ & $\begin{array}{c}\Delta \sigma^{2} \\
{\left[\AA^{2}\right]} \\
10^{-3}\end{array}$ & & \\
\hline$\beta$-Ni hydroxide & 5.9 & 2.06 & 5.3 & 5.8 & 3.13 & 5.3 & 0.2 & 6.9 \\
\hline$\alpha$-Ni hydroxide & 5.8 & 2.04 & 4.9 & 5.5 & 3.09 & 5.8 & 3.6 & 9.3 \\
\hline Ni phyllosilicate & 5.8 & 2.06 & 3.8 & 6.7 & 3.08 & 2.8 & 3.9 & 10.9 \\
\hline syn. Ni-Al LDH & 6.0 & 2.05 & 4.6 & 2.8 & 3.06 & 4.2 & 4.1 & 9.2 \\
\hline takovite & 5.3 & 2.05 & 3.5 & 3.1 & 3.06 & 5.4 & 1.4 & 10.5 \\
\hline $\mathrm{Ni} /$ cement & 5.9 & 2.05 & 4.4 & 2.7 & 3.09 & 4.7 & 0.8 & 4.7 \\
\hline $\mathrm{Ni} / \mathrm{csh}$ & 5.7 & 2.06 & 6.4 & 6.4 & 3.10 & 6.5 & 0.2 & 7.2 \\
\hline $\mathrm{Ni} /$ quartz & 6.0 & 2.05 & 6.7 & 6.3 & 3.10 & 6.1 & 1.2 & 8.4 \\
\hline $\mathrm{Ni} /$ portlandite & 6.0 & 2.06 & 5.9 & 5.1 & 3.13 & 6.0 & 0.4 & 10.0 \\
\hline $\mathrm{Ni} /$ gibbsite & $6.0^{\mathrm{f}}$ & 2.04 & 5.9 & 3.2 & 3.06 & 6.1 & 0.1 & 18.4 \\
\hline
\end{tabular}

$\mathrm{CN}, \mathrm{R}, \Delta \sigma^{2}, \Delta \mathrm{E}_{\mathrm{O}}$ stand for the coordination numbers, interatomic distances, DebyeWaller factors, and inner potential corrections

f: Fixed parameter during fitting.

$\chi_{\text {res\% }}^{2}$ : Deviation between experimental data and fit given by the relative residual in percent. $\mathrm{N}$ represents the number of data points, and $\mathrm{y}_{\exp }$ and $\mathrm{y}_{\text {theo }}$ the experimental and theoretical data points, respectively.

$\% \operatorname{Res}=\frac{\sum_{i=1}^{N}\left|y_{\text {exp }}(i)-y_{\text {theo }}(i)\right|}{\sum_{i=1}^{N} y_{\text {exp }}(i)} .100$

$\mathrm{Ni}-\mathrm{Ni}$ distances in the sorption samples are $3.06 \AA$ for the Ni treated gibbsite sample, $3.09 \AA$ for the Ni treated cement sample, $3.10 \AA$ for the Ni/quartz and $\mathrm{Ni} / \mathrm{csh}$ samples, and $3.13 \AA$ for $\mathrm{Ni} /$ portlandite. The last distance agrees well with $\mathrm{Ni}-\mathrm{Ni}$ distances in $\beta-\mathrm{Ni}(\mathrm{OH})_{2}$. The $\mathrm{Ni}-\mathrm{Ni}$ distances in the $\mathrm{Ni} /$ quartz and $\mathrm{Ni} / \mathrm{csh}$ samples appear to be slightly longer than the $\mathrm{Ni}-\mathrm{Ni}$ distances in $\alpha-\mathrm{Ni}(\mathrm{OH})_{2}$ and Ni-phyllosilicates (3.06-3.08 ̊; Mellini, 1982; Scheinost et al., 
2000). Furthermore, an $\mathrm{R}_{\mathrm{Ni}-\mathrm{Ni}}$ of $3.09 \AA$ for the cement sample seems to be on the longer side for Ni-Al LDHs (3.03-3.07 $\AA$; Scheidegger et al., 1998; Malherbe et al., 1999; Thompson et al.; 1999).

We suspect that the longer $\mathrm{Ni}-\mathrm{Ni}$ distances observed in the $\mathrm{Ni}$ /quartz, $\mathrm{Ni} /$ csh and $\mathrm{Ni} /$ cement sample are caused by the presence of a fraction of $\beta-\mathrm{Ni}(\mathrm{OH})_{2}$. The formation of at least some $\beta-\mathrm{Ni}(\mathrm{OH})_{2}$ in the samples would not be surprising. $\beta-\mathrm{Ni}(\mathrm{OH})_{2}$ is the thermodynamically more stable than $\alpha-\mathrm{Ni}(\mathrm{OH})_{2}$ and the phase expected to be formed in solution under the highly alkaline reaction conditions. Indeed, Fig. 1 and data analysis suggest that in the $\mathrm{Ni}$ /portlandite sample $\beta-\mathrm{Ni}(\mathrm{OH})_{2}$ and not $\alpha-\mathrm{Ni}(\mathrm{OH})_{2}$ is formed. To test whether a mineral mixture would be consistent with the observed cement spectrum, we fitted the XAFS spectrum of the $\mathrm{Ni}$-treated cement with linear combinations of various reference compounds. Best fits were obtained with $\sim 10 \% \beta-\mathrm{Ni}(\mathrm{OH})_{2}$ and $\sim 90 \% \mathrm{Ni}-\mathrm{Al} \mathrm{LDHs}$ (Ni/cement sample). Still, the results support our hypothesis that $\mathrm{Ni}$ is predominately fixed in $\mathrm{Ni}-\mathrm{Al} \mathrm{LDHs}$.

Further evidence in support of the formation of $\mathrm{Ni}-\mathrm{Al}$ LDHs in $\mathrm{Ni}$ treated cement and gibbsite samples is provided by diffuse reflectance spectroscopy (DRS). The band positions of $\mathrm{Ni}$ in $\mathrm{Ni}$ treated cement and in Ni treated gibbsite are fully in accord with the band positions of various Ni-Al LDH phases. Further details on DRS and the experimental results are presented elsewhere (Scheinost et al., 1999b; Scheidegger et al., 2000).

In conclusion, the XAFS study demonstrates that Ni-Al LDH phases can be formed when cement is treated with Ni under highly alkaline conditions $(\mathrm{pH}=13.3)$. Furthermore, the study reveals that depending on the mineral surface present in the experimental system (csh, quartz, or portlandite) a different Ni phase can be formed. This work may lead to new approaches for modeling heavy metal binding in cement and cement systems and may allow better predictions of the performance of cement-based landfills and nuclear waste repositories.

\section{Acknowledgments:}

We thank Kaumudi Pandya (Brookhaven National Laboratory, Upton, NY) for her support during the XAFS measurements. Partial financial support was provided by the National Co-operative for the Disposal of Radioactive Waste (Nagra), Wettingen, Switzerland.

\section{References}

Atkins, M., Glasser, F. P., Moroni, L. P. \& Jack J. J. (1994). DoE report, DoE/HMIP/RR/94.011. pp. 1-194.

Bellotto, M., Rebours, B., Clause, O. \& Lynch, J. (1996). J. Phys. Chem. 100, 8527-8534.

Bish, D. L. \& Brindley, G. W. (1977). Amer. Mineral. 62, 458-464.

Boclair, J. W. \& Braterman, P. S. (1999). Chemistry of Materials 11, 298 302.

Cavani, F., Trifiro, F. \& Vaccari, A. (1991). Catal. Today 11, 173-301.

Charlet, L. \& Manceau, A. (1994). Geochim. Cosmochim. Acta 58, $2577-$ 2582.

Glasser, F. P. (1993). Chemistry and microstructure of solidified waste forms. edited by R. D. Spence, pp 1-39. Lewis Publishers.

Gougar, M. L. D., Scheetz, B. E. \& Roy, D. M. (1996). Waste Management 16(4), 295-303.

Malherbe, F. B. L., Forano C., de Roy, A., \& Besse, J. P. J. (1999). Chem. Soc. Dalton Trans, 3831-3839.

Manceau, A. \& Calas, G. (1985). Clay Minerals 20, 367-387.

Manceau, A. \& Calas, G. (1986). Clay Minerals 21, 341-360.

Manceau, A., Schlegel, M., Nagy, K. L. \& Charlet, L. (1999). J. Colloid
Interface Sci 220, 181-197.

Mellini, C. (1982). Am. Mineral. 67, 587-598.

O'Day, P. A., Rehr, J. J., Zabinsky, S. I. \& Brown, Jr. G. E.(1994). J. Am. Chem. Soc. 116, 2938-2949.

Rehr, J. J., Mustre de Leon, J., Zabinsky, S., \& Albers, R. C. (1991). J. Am. Chem. Soc. 113, 5135-5140.

Ressler, T. J. (1998). Synchr. Rad. 5, 118-122.

Scheidegger, A. M., Lamble, G. M. \& Sparks, D. L. (1997). J. Colloid Interface Sci. 186, 118-128.

Scheidegger, A. M., Strawn, D. G., Lamble, G. M. \& Sparks, D. L. (1998). Geochim. Cosmochim. Acta 62, 2233-2245.

Scheidegger, A. M., Wieland, E., Scheinost, A. C., Dähn, R. \& Spieler, P. (2000). Environ. Sci. Technol. 34, 4545-4548.

Scheinost, A. C., Ford, R. G. \& Sparks, D. L. (1999a). Geochim. Cosmochim. Acta 63, 3193-3203.

Scheinost, A. C., Schulze, D. G. \& Schwertmann, U. (1999b). Clays \& Clay Minerals 47, 156-164.

Scheinost, A. C. \& Sparks, D. L. (2000). J. Colloid Interface Sci. 223, 167178.

Schlegel, M., Manceau, A., Charlet, L., Chateigner, D., Hazemann, J. L. (2001). Geochim. Cosmochim. Acta 63, in review.

Thompson, H. A., Parks, G. A. \& Brown, Jr. G. E. (1999). Clays \& Clay Minerals 47, 425-438.

Tits, J., Wieland, E., Bradbury, M. H. \& Dobler, J. P. (2000). ICAM 2000 Extended Abstract, $6^{\text {th }}$ Int. Conf on Applied Mineralogy. Göttingen, Germany. In press.

Towle, S. N., Bargar, J. R., Brown, J. G. E. \& Parks, G. A. J. (1997). J. Colloid Interface Sci. 187, 62-82.

Wieland, E., Tits, J., Spieler, P. \& Dobler, J. P. (1998). Mat. Res. Soc. Symp. Proc. 506, 573-578. 